\title{
Słowo wstępne
}

Publikacja, którą oddajemy w Państwa ręce, stanowi próbę refleksji nad zagadnieniem wszechogarniającym oraz trudnym do całościowego uchwycenia i przedstawienia - dotyczy bowiem różnorodnych sposobów reakcji władzy publicznej na szerokie spektrum, kształtujących się współcześnie niezwykle dynamicznie, problemów społecznych i gospodarczych. Artykuły zawarte w niniejszym tomie, przygotowane przede wszystkim przez pracowników i doktorantów Wydziału Prawa, Administracji i Ekonomii Uniwersytetu Wrocławskiego, koncentrują się wokół prawnych aspektów wskazanej problematyki. Całokształt wynikających z nich tez i konkluzji powinien skłaniać do refleksji nad stopniem realizacji w polskim prawie rzymskiej paremii Hominem causa omne ius constitutum sit a więc czy ustawodawca kreuje prawne instrumenty oddziaływania na współczesne problemy społeczne i gospodarcze, w rzeczy samej, ze względu na człowieka, jego potrzeby, dążenia i interesy?

Trójdzielna struktura niniejszej publikacji odzwierciedla różnorodność ról, w których człowiek występuje względem władzy publicznej — jako członek społeczeństwa, jednostka pragnąca bezpieczeństwa i dobrostanu, a niekiedy także podmiot działalności gospodarczej. Artykuły w niej zawarte stanowią w większości rozwinięcie stanowisk wyrażonych w ramach referatów przedstawionych na Międzynarodowej Konferencji Naukowej „Prawo i administracja wobec współczesnych problemów społecznych, gospodarczych i międzynarodowych”, która odbyła się w dniach 9-10 czerwca 2017 r. na Wydziale Prawa, Administracji i Ekonomii Uniwersytetu Wrocławskiego z udziałem delegacji z Rosji, Ukrainy, Czech i Chile.

Organizacja konferencji oraz wydanie tegoż tomu nie byłyby możliwe bez życzliwości i wsparcia przedstawicieli Urzędu Marszałkowskiego Województwa Dolnośląskiego oraz Wydziału Prawa, Administracji i Ekonomii Uniwersytetu Wrocławskiego, którym pragniemy serdecznie podziękować.

Tadeusz Kocowski

Witold Matecki 